\title{
Evaluating Potential Economic Effects of an Industrial Road on Subsistence in North-Central Alaska
}

\author{
Mouhcine Guettabi, ${ }^{1}$ Joshua Greenberg, ${ }^{2}$ Joseph Little $^{3}$ and Kyle Joly ${ }^{4}$
}

(Received 17 February 2016; accepted in revised form 25 May 2016)

\begin{abstract}
Northwest Alaska is one of largest inhabited, roadless areas in North America and, indeed, the world. A new road has been proposed to provide access to this region and the Ambler Mining District from north-central Alaska. To evaluate how new road access might affect subsistence harvest, we used zero inflated negative binomial models to identify factors related to subsistence production at the household level. We found substantial differences in these factors between communities near the proposed road (project zone [PZ] communities) and a comparable set of road accessible communities outside the region (non-project zone [NPZ] communities). Total subsistence production of PZ communities was 1.8 to 2.5 times greater than that of NPZ communities. If the road was opened to the public and subsistence harvest patterns for PZ communities changed to mirror existing NPZ harvests as a result of the road, the financial cost would be US\$6900-10 500 per household (assuming a $\$ 17.64 / \mathrm{kg}$ "replacement" cost for subsistence harvests). Taken together, our results suggest that the proposed road should be expected to substantially impact subsistence production in communities that are not currently connected to the road system.
\end{abstract}

Key words: Alaska; development; hunting; mining; roads; subsistence

RÉSUMÉ. Le nord-ouest de l'Alaska est l'une des plus grandes régions habitées de l'Amérique du Nord, voire du monde, qui n'a pas de routes. Une nouvelle route a été proposée pour donner accès à cette région de même qu'au district minier Ambler dans le centre-nord de l'Alaska. Afin d'évaluer l'effet de l'accès que procurerait cette nouvelle route sur les récoltes de subsistance, nous nous sommes servis de modèles binomiaux négatifs à inflation de zéros pour déterminer les facteurs se rapportant à la production de subsistance des ménages. Nous avons relevé des différences considérables sur le plan de ces facteurs entre les communautés situées près de la route proposée (les communautés de la zone du projet [PZ]) et un ensemble comparable de communautés accessibles par voie routière à l'extérieur de cette région (les communautés de la zone non visée par le projet [NPZ]). Chez les communautés PZ, la production de subsistance totale était de 1,8 à 2,5 fois plus grande que celle des communautés NPZ. Si la route était ouverte au public et que les tendances en matière de récolte de subsistance au sein des communautés visées par la PZ changeaient au point de refléter les récoltes actuelles de la NPZ en raison de la route, le coût financier serait de l'ordre de 6900 \$à 10500 \$ US par ménage (en présumant un coût de « remplacement» de 17,64 \$/kg pour les récoltes de subsistance). Considérés ensemble, nos résultats suggèrent que la route proposée devrait avoir une incidence substantielle sur la production de subsistance au sein des communautés qui ne sont actuellement pas reliées au réseau routier.

Mots clés : Alaska; développement; chasse; exploitation minière; routes; subsistance

Traduit pour la revue Arctic par Nicole Giguère.

\section{INTRODUCTION}

Roads can have profound effects on human socioeconomics, demographics, and lifestyles. They provide connectivity with the outside world, which can lower the cost of goods and services such as heating oil and groceries (McDowell Group, 2009). However, an influx of new residents can create social turmoil in small towns and villages (Power, 1996; Mittermeier et al., 2003). Rural residents living off the road system are tied to the landscape around them and may have traditions, practices, and norms very different from those of new arrivals from other areas (Berger and Daneke, 1988; Fuller, 2007). Thus, the establishment of roads into previously roadless areas can have both positive and negative elements.

Roads can also have profound effects on wildlife and wildlife habitat (Forman et al., 2003). Roads directly and indirectly impact the amount of habitat that is available to wildlife (Walker and Everett, 1987; Forman et al., 2003; Gude et al., 2007; Wilson et al., 2014). Roads increase

\footnotetext{
${ }^{1}$ Institute of Social and Economic Research, University of Alaska Anchorage, 3211 Providence Drive, Anchorage, Alaska 99508, USA

${ }^{2}$ School of Natural Resources and Extension, University of Alaska Fairbanks, Fairbanks, Alaska 99775, USA

${ }^{3}$ Corresponding author: School of Management, University of Alaska Fairbanks, Fairbanks, Alaska 99775, USA; jmlittle2@alaska.edu

${ }^{4}$ National Park Service, Gates of the Arctic National Park and Preserve, 4175 Geist Road, Fairbanks, Alaska 99709, USA

(C) The Arctic Institute of North America
} 
habitat fragmentation and reduce connectivity, potentially affecting wildlife migrations, behavior, and genetic flow (McLellan and Shackleton, 1988; Forman and Alexander, 1998; Berger, 2004). Poaching of wildlife may be facilitated by road access (Cole et al., 1997; Berger and Daneke, 1988; Haines et al., 2012). Further, road access has the potential to increase competition between rural and urban residents for game and fish resources. While diminished subsistence harvests have been linked to road access (Wolfe and Walker, 1987), the mechanism by which access affects competition has not been well studied.

Subsistence is living off the land. In the Arctic, living off the land is primarily accomplished through hunting, fishing, and gathering. Further, subsistence activities are integral to the identity, culture, ceremonies, and traditions of a large segment of rural residents in the region (Wolfe and Walker, 1987; Brown and Burch, 1992; Whiting, 2004; Wolfe, 2004). The Alaska National Interest Lands Conservation Act (ANILCA) defines subsistence as the "customary and traditional uses by rural Alaska residents of wild, renewable resources for...food, shelter, fuel, clothing, tools, or transportation" (U.S. Public Law 96-487, Section 803). The subsistence lifestyle is pervasive in rural areas of the Arctic, including north-central Alaska (Anderson et al., 1977; Wolfe and Walker, 1987; Wolfe, 2004; Holen et al., 2012; Braem et al., 2015; Fall, 2016). Often limited employment is also available, so many residents engage in a mixed subsistence-market economy, in which subsistence provides vital resources that augment household cash income (Wolfe and Walker, 1987; Kruse, 1991).

In November 2015, the Alaska Industrial Development and Export Authority, a public corporation of the State of Alaska, applied for a right-of-way for an industrial road more than $320 \mathrm{~km}$ long leading from the existing contiguous road system to the Ambler Mining District in north-central Alaska (Fig. 1). Currently, this inhabited region is one of the largest roadless blocks of its kind in North America and perhaps the world. The proposed route would go along the southern foothills of the Brooks Range and traverse a mix of private lands (e.g., Alaska Native regional and village corporation lands) and federal lands (e.g., Bureau of Land Management), including 27-42 km of the "Kobuk Preserve" section in the southwestern portion of Gates of the Arctic National Park and Preserve, as well as vast tracks of state land. The proposed road would not directly connect any villages, though connecting them may be a possibility. The stated purpose for the road was to support mining operation, and access would be limited to vehicles engaged in that activity: the road would not be open to the public.

The Dalton Highway, leading to the oil fields on Alaska's North Slope, was initially developed as an industryonly road, but it was opened to public use in relatively short order, within seven years with a permit and 20 years without. So, while the initial right-of-way application has called for the new road to be open for industrial use only, and not to the general public, the precedent set by the Dalton
Highway makes public access on the road to the Ambler Mining District reasonably foreseeable, especially since the route accesses public lands. Moreover, the project's proponents have noted that there are multiple options to increase public access on the road (Brehmer, 2014). Given that public access to the road cannot be ruled out, we assessed the potential impacts of this alternative. Impacts of public access were a specific concern expressed by some rural residents within the study area (Yarnell, 2013; Buxton, 2014a, b; Watson, 2014).

Our goal was to assess the potential impacts on subsistence activities of developing a new, industrial road to the Ambler Mining District. Specifically, we wanted to determine what factors are related to 1) whether a household engages in subsistence activities and 2) the subsistence production of households. Further, we wanted to assess how outside competition for fish and game resources might affect reported subsistence participation and harvest quantities. We also calculated a set of replacement values using estimates presented by Fall (2014).

\section{STUDY AREA}

The study area lies entirely above the Arctic Circle (Fig. 1) and is bounded to the north by the central Brooks Range, sparsely vegetated, rugged mountains that reach up to $2600 \mathrm{~m}$. To the south lie extensive boreal forest habitats interspersed with minor mountain ranges. The Dalton Highway forms the eastern boundary, and the village of Ambler the western boundary. Within the study area, boreal forest, dominated by black spruce (Picea mariana), carpets the lowlands, while wetland and riparian complexes are extensively interspersed. Tundra communities dominate areas where permafrost is prevalent. At higher elevations, boreal forests transition into sub-alpine shrublands and alpine tundra. The climate is strongly continental, with winter temperatures dropping below $-40^{\circ} \mathrm{C}$ and highs in summer reaching more than $20^{\circ} \mathrm{C}$. Snow cover typically lasts from October to May, with a mean annual snowfall of about $120 \mathrm{~cm}$ (NCEI, 2015).

The region contains intact ecosystems with the full complement of native fish and wildlife species, including predators. Critical subsistence species include moose (Alces alces), caribou (Rangifer tarandus), salmon (Oncorhynchus spp.), sheefish (Stenodus leucichthys), and other whitefish. Subsistence activities take place year-round (Watson, 2014). Non-rural hunters access this region primarily by airplane, which limits competition for wild renewable resources.

The villages of Alatna, Allakaket, Bettles, Coldfoot, Evansville, and Wiseman lie to the east of the continental divide, while Ambler, Kobuk, and Shungnak are on the west side. The village of Anaktuvuk Pass lies within the Brooks Range and Gates of the Arctic National Park and Preserve. We termed these villages project zone (PZ) communities. The regulations established to implement ANILCA (Norris, 2002) consider them resident zone communities of 


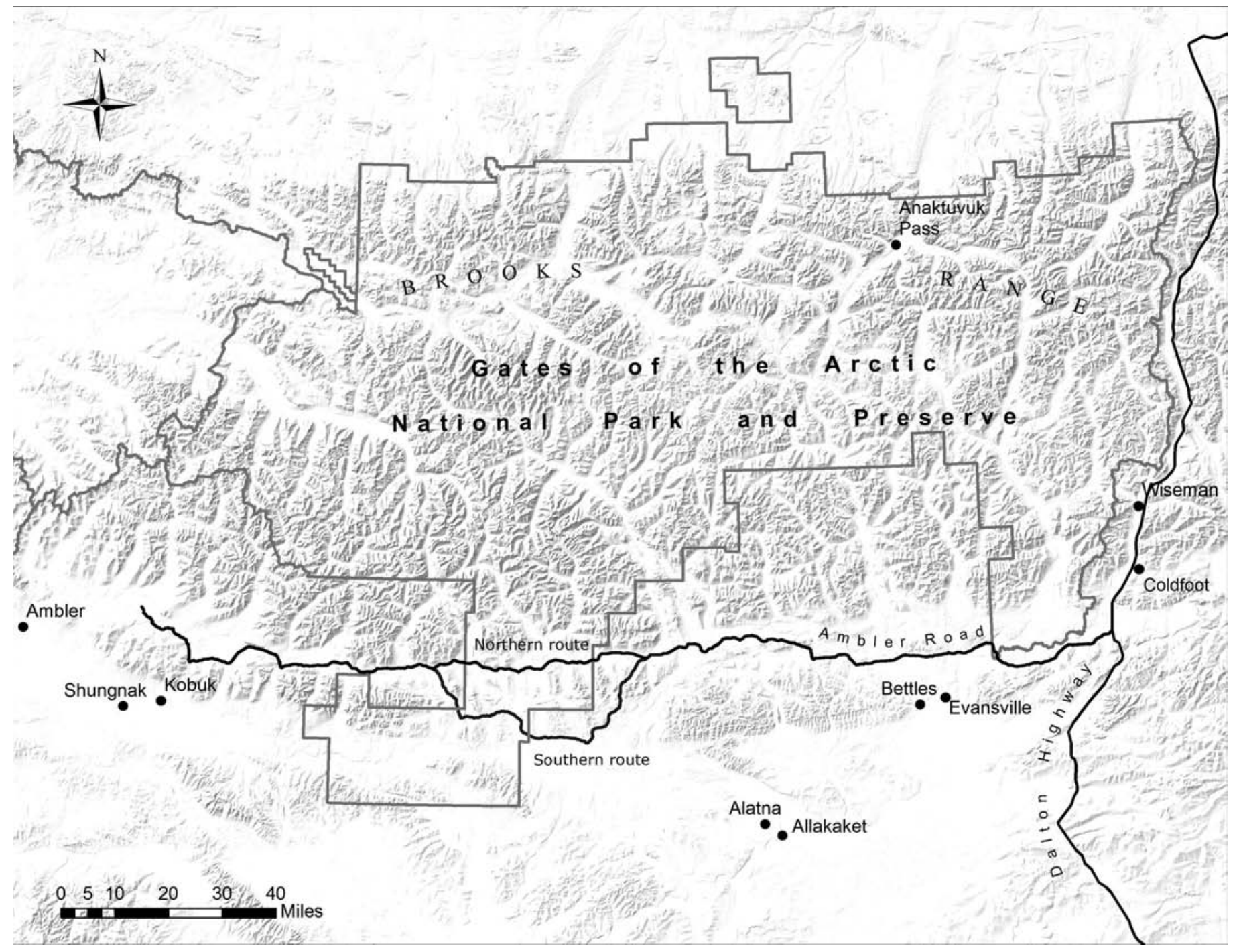

FIG. 1. The study area used to assess the potential economic impacts on subsistence from a proposed road that would connect the existing road network to the Ambler Mining District in north-central Alaska.

the national park and preserve, thus granting their residents federal subsistence privileges within it. Alaska Natives of Athabascan descent typically dominate villages on the east side, while Natives of Inupiat descent dominate on the west side. Village populations range from 10 to 310 (Table 1; ADF\&G, 2015). In the east, the communities of Wiseman and Coldfoot are connected to the Dalton Highway, and Evansville and Bettles are connected in winter via an ice road accessible from the Dalton Highway.

\section{PZ and NPZ Household Data}

We used existing household data collected by the Subsistence Division of the Alaska Department of Fish and Game. The household surveys, in addition to information on the distribution and uses of wild resources and their harvest (e.g., kilograms of moose harvested), provide socioeconomic and demographic information about the communities (Fall, 1990, 2016; Wheeler and Thornton, 2005). Household surveys were conducted in the study area communities in 2011 and 2012 (Braem et al., 2015; community summaries of the household surveys are available through the Community Subsistence Information System (https://www.adfg.alaska.gov/sb/CSIS/).

To broaden the evaluation of subsistence production and to better distinguish harvest patterns between on-road and off-road communities, we included household survey data from other interior Alaska and Copper River region communities that are not located near the proposed Ambler road corridor (Table 1). We considered these non-project zone (NPZ) communities. While the NPZ communities had poorer access to whitefish and caribou than PZ communities, they had better access to salmon and moose. NPZ communities, in general, are closer to the population centers of Alaska. The PZ and NPZ regions have somewhat different characteristics, but because we had data from similar time periods, these regions provide the best comparison between a rural region dominated by communities with road access and the roadless set of PZ communities. Survey data for the NPZ communities, with populations ranging 
TABLE 1. List of communities used to analyze the potential impact on subsistence production of a proposed new road to the Ambler Mining District. "\% Alaska Native" is the percentage of households headed by an Alaska Native.

\begin{tabular}{|c|c|c|c|c|c|c|}
\hline Community & On road & Region & Population & Per capita harvest (kg) & Per household harvest (kg) & $\%$ Alaska Native \\
\hline Alatna & No & $\mathrm{PZ}$ & 32 & 124.10 & 434.32 & 100.0 \\
\hline Allakaket & No & PZ & 147 & 236.00 & 606.86 & 88.1 \\
\hline Ambler & No & PZ & 282 & 276.74 & 1028.70 & 67.9 \\
\hline Anaktuvuk Pass & No & PZ & 310 & 143.70 & 523.72 & 83.9 \\
\hline Beaver & No & NPZ & 72 & 162.75 & 325.50 & 100.0 \\
\hline Bettles & Yes $^{1}$ & PZ & 12 & 79.51 & 119.29 & 0.0 \\
\hline Chistochina & Yes & NPZ & 87 & 73.29 & 192.73 & 40.7 \\
\hline Chitina & Yes & NPZ & 134 & 111.49 & 276.37 & 28.3 \\
\hline Coldfoot & Yes & PZ & 10 & 17.28 & 34.61 & 0.0 \\
\hline Copper Center & Yes & NPZ & 431 & 95.75 & 260.95 & 32.5 \\
\hline Dot Lake & Yes & NPZ & 50 & 53.93 & 127.14 & 57.1 \\
\hline Dry Creek & Yes & NPZ & 91 & 64.82 & 196.90 & 0.0 \\
\hline Evansville & Yes $^{1}$ & $\mathrm{PZ}$ & 20 & 23.95 & 36.88 & 46.2 \\
\hline Gakona & Yes & NPZ & 202 & 77.75 & 203.66 & 14.3 \\
\hline Glennallen & Yes & NPZ & 384 & 44.27 & 121.34 & 3.9 \\
\hline Gulkana & Yes & NPZ & 104 & 65.41 & 205.25 & 72.4 \\
\hline Kenny Lake & Yes & NPZ & 179 & 148.73 & 149.01 & 3.0 \\
\hline Kobuk & No & $\mathrm{PZ}$ & 164 & 140.02 & 639.34 & 66.7 \\
\hline Lake Louise & Yes & NPZ & 27 & 33.11 & 62.91 & 0.0 \\
\hline McCarthy Road & Yes & NPZ & 103 & 39.37 & 69.63 & 2.6 \\
\hline Mendeltna & Yes & NPZ & 34 & 23.86 & 57.33 & 0.0 \\
\hline Mentasta Lake & Yes & NPZ & 106 & 68.45 & 202.39 & 82.6 \\
\hline Mentasta Pass & Yes & NPZ & 35 & 86.00 & 248.43 & 11.1 \\
\hline Nelchina & Yes & NPZ & 76 & 58.24 & 152.04 & 0.0 \\
\hline Paxson & Yes & NPZ & 32 & 97.07 & 279.10 & 0.0 \\
\hline Shungnak & No & $\mathrm{PZ}$ & 275 & 166.70 & 663.11 & 76.1 \\
\hline Slana & Yes & NPZ & 176 & 92.17 & 188.79 & 4.8 \\
\hline Tazlina & Yes & NPZ & 352 & 68.08 & 199.90 & 32.9 \\
\hline Tok & Yes & NPZ & 1312 & 99.20 & 236.10 & 7.0 \\
\hline Tolsona & Yes & NPZ & 24 & 140.98 & 281.91 & 0.0 \\
\hline Tonsina & Yes & NPZ & 90 & 90.41 & 208.34 & 4.3 \\
\hline Wiseman & Yes & PZ & 13 & 133.22 & 346.41 & 0.0 \\
\hline
\end{tabular}

${ }^{1}$ Via a winter ice road.

from 24 to 1312 persons, were collected in 2009 and 2013 (Kukkonen and Zimpelman, 2012; La Vine et al., 2013; La Vine and Zimpelman, 2014; Holen et al., 2015).

\section{Community Comparisons of Per Capita Subsistence Harvest}

Along with their relative inaccessibility, PZ communities were also defined by their dependence on subsistence activity. Each of the PZ communities off the road system exceeded the Alaska rural population average per capita harvest of $137 \mathrm{~kg}$ (Fall, 2014, 2016). The (edible) per capita subsistence harvest in the households of PZ communities averaged $165.7 \pm 38.5 \mathrm{~kg}$ and ranged from $17.28 \mathrm{~kg}$ in Coldfoot to $276.74 \mathrm{~kg}$ in Ambler (ADF\&G, 2015). Among the PZ communities not connected to the road system (i.e., all except Wiseman, Coldfoot, Bettles, and Evansville), the per capita subsistence production $(245.1 \pm 30.1 \mathrm{~kg})$ was more than double the production of NPZ communities situated on the road system $(118.9 \pm 16.1 \mathrm{~kg})$ and more than five times the production of $\mathrm{PZ}$ communities on the road system $(46.6 \pm 36.8 \mathrm{~kg})$.

A similar pattern of subsistence production differences occurs when production is examined at the household level across the PZ and NPZ regions. Among respondent households across PZ communities, average subsistence production at the household level was $443.2 \pm 317 \mathrm{~kg}$, more than double the average of households across NPZ communities $(193.0 \pm 73.6 \mathrm{~kg})$. The difference is even more pronounced when comparing subsistence production of households across PZ communities off the road system $(649.2 \pm 203 \mathrm{~kg})$ to that of households across NPZ communities connected to the road system $(186.9 \pm 69.0 \mathrm{~kg})$.

Caribou, moose, and fish harvests accounted for the vast majority of subsistence production. Among surveyed households, these resources accounted for an average of $92.3 \%$ of all subsistence production in the larger PZ communities ( $\geq 40$ households) and $82.8 \%$ in the smaller communities. These three resources averaged $87.2 \%$ of total subsistence production in NPZ communities. Average harvests of whitefish and caribou were significantly higher in PZ communities than in NPZ communities; therefore, moose and salmon harvests were typically more prevalent in NPZ households than in their PZ counterparts. The importance of fish as a subsistence resource to many community households is underscored by the fact that for several communities (e.g., Kobuk, Allakaket, and Tazlina), the fish harvest exceeded the combined harvest of caribou and moose. With few exceptions, the most prominent fish species harvested by the PZ communities were salmon, 
sheefish, and whitefishes (other than sheefish). The composition of species harvested by households depended on community location and resource availability. For example, the Western Arctic Herd caribou typically migrate through the Kobuk River Valley twice a year (Joly, 2012) and caribou are a prominent subsistence food resource for the three western PZ communities. Caribou is also reported to be an essential resource for Anaktuvuk Pass households, not only as food, but also as an important part of community identity and culture for the Nunamiut who "have lived alongside caribou in the Brooks Range for thousands of years" (Holen et al., 2012:130). Annual variation in the abundance and distribution of ungulate and fish resources affects subsistence participation and harvests (Fall, 2016).

While participation in and distribution of subsistence harvests is pervasive in rural Alaska communities, most of the production comes from relatively few households and is affected by social factors (Wolfe, 1987; Wolfe et al., 2009). In the larger PZ communities, approximately $30 \%$ of the households produced $74 \%$ to $87 \%$ of the subsistence resources, according to the ADF\&G household surveys. The concentration of harvesting in a few households was less pronounced in the smaller communities, with the exception of Alatna, but even in these communities, $50 \%$ of the households accounted for $79 \%$ of subsistence harvests.

\section{METHODS}

\section{Modeling Subsistence Harvest}

We developed models to highlight linkages between observed household and community characteristics and subsistence production. For each model, reported household harvests (edible weight in $\mathrm{kg}$ ) served as the dependent variable. Models conformed to the general equation:

$$
y_{\mathrm{i}}=\alpha_{\mathrm{i}}+\beta_{1} X_{\mathrm{i}}+\beta_{2} C_{\mathrm{i}}+e_{\mathrm{i}}
$$

where $y_{\mathrm{i}}$ was the number of edible kilograms reported for household $i, X_{\mathrm{i}}$ represented the set of household level characteristics for household $i$, and $C_{\mathrm{i}}$ was the set of community level characteristics associated with household $i$.

We estimated parameters for six models, using the following dependent variables (expressed as edible weight in kilograms for each household): (1) the sum of the caribou and moose harvests; (2) the sum of the salmon, whitefish, and sheefish harvests; and then the harvests for specific species: (3) moose, (4) caribou, (5) salmon, and (6) whitefish (including sheefish). The set of covariates used in the analysis, their definitions, and descriptive statistics were broken down by study region (PZ versus NPZ; Table 2). Variance weighted t-tests were used to identify statistically significant differences in means between the PZ and NPZ subsamples $(p<0.05)$.

For the set of household characteristics $\left(X_{\mathrm{i}}\right)$, reported household income from all sources was separated into five categories $(<\mathrm{US} \$ 25 \mathrm{~K}, \$ 25 \mathrm{~K}-\$ 50 \mathrm{~K}, \$ 50 \mathrm{~K}-\$ 75 \mathrm{~K}$, $\$ 75 \mathrm{~K}-\$ 100 \mathrm{~K}$, and $>\$ 100 \mathrm{~K}$ ) and modeled using a set of indicator variables (taking the value of 1 if income falls inside the bounds of the income grouping and zero otherwise). A total of four indicator variables accounting for income categories are included in each model, and coefficients are interpreted relative to households reporting less than $\$ 25 \mathrm{~K}$ (the first income category), which served as the baseline of comparison. The number of individuals living in a household and the number of children age 10 years or younger in each household were identified and incorporated into model estimates. Alaska Native households (as determined by the ethnicity of the household head) and femaleheaded households were identified using dichotomous indicator variables.

Community-level variables $\left(C_{\mathrm{i}}\right)$ include a dichotomous indicator that identified households located in PZ communities. The inclusion of a specific regional control allowed us to estimate the extent to which subsistence participation and harvest production differed between the two regions. For models in which dependent variables included the combined caribou + moose harvest, as well as separate harvests of caribou and moose, we included a sixyear average number of non-local hunters of these species who reported hunting in game management sub-units where study communities were located. If the combined caribou + moose harvest served as the dependent variable, we used the sum of the six-year average numbers of nonlocal moose hunters and caribou hunters in the analysis. The incorporation of six-year averages for non-local hunters served as a proxy to assess the influence that outside competition might have on reported subsistence participation and harvest quantities.

\section{Data Analysis}

Two factors complicated model estimation. First, a significant number of surveyed households either did not pursue or did not report the subsistence harvest of moose, caribou, salmon, or whitefish. Consequently, the harvest data include a large number of zeros (indicating no harvest). Second, reported harvest quantities were not normally distributed across households. For a large number of households reporting subsistence harvest, the quantities were relatively small and mass towards zero. This result was consistent with the observed pattern: that the bulk of subsistence harvest was concentrated within a small proportion of community households. These data characteristics can lead to biased estimates when evaluated using traditional linear regression. To address this issue, our approach used the Zero Inflated Negative Binomial (ZINB) framework to obtain parameter estimates (Lambert, 1992; Cameron and Trivedi, 1998). The ZINB framework involves the estimation of two separate models, one that controls for the presence of zeros in the harvest data and a second that models the positive harvest count: 
TABLE 2. Parameters used to model household subsistence production in north-central Alaska, showing means ( \pm SD) for households in non-project and project zones.

\begin{tabular}{lrr}
\hline \hline Definition & Non-project zone & Project zone \\
\hline $\mathrm{kg}$ of caribou harvested & $16.84(44.63)$ & $316.26(647.89)^{1}$ \\
$\mathrm{~kg}$ of moose harvested & $43.96(107.15)$ & $38.77(101.40)$ \\
$\mathrm{kg}$ of salmon harvested & $96.99(211.17)$ & $81.66(267.64)$ \\
kg of whitefish harvested & $3.05(16.74)$ & $127.73(405.23)^{1}$ \\
Number of children age $\leq 10$ & $0.36(0.82)$ & $0.80(0.95)^{1}$ \\
Female head of household & $0.16(0.37)$ & $0.22(0.38)^{1}$ \\
Number of people living in the household & $2.52(1.56)$ & $3.46(2.40)^{1}$ \\
Alaska Native head of household & $0.20(0.40)$ & $0.72(0.46)^{1}$ \\
Reported annual income & $51327(48519)$ & $52653(46664)$ \\
Average age of individuals & $52.59(14.88)$ & $49.99(15.19)^{1}$ \\
Six-year average number of non-local moose hunters & $605.42(437.81)$ & $242.73(421.44)^{1}$ \\
Six-year average number of non-local caribou hunters & $328.35(577.11)$ & $89.68(522.03)^{1}$ \\
Number of communities & 21 & 10 \\
Mean community population & $388.068(426.886)$ & $0.290(0.303)$ \\
Proportion Alaska Native & & $220.78(96.466)^{1}$ \\
\hline \hline
\end{tabular}

${ }^{1}$ Indicates significant difference.

$$
y_{i} \sim\left\{\begin{array}{c}
0 \text { with probability } \pi_{i} \\
f\left(y_{i} \mid x_{i}\right) \text { with probability }\left(1-\pi_{i}\right)
\end{array}\right\}
$$

where $y_{\mathrm{i}}$ was the harvest quantity for household $i, x_{\mathrm{i}}$ was a vector of covariates for household $i$, and $\pi_{\mathrm{i}}$ was the probability of zero harvest being associated with household $i$. In the first stage, a logit model was used to estimate the probability that a household did not report a harvest quantity for the species harvest being modeled. The logit model regressed a dichotomous dependent variable on the set of household and community level covariates. This variable was given a value of one when household harvest quantity was reported as a zero and the value of zero when a positive harvest quantity was reported, so that:

$$
q_{i} \sim\left\{\begin{array}{l}
1 \text { if } y_{i}=0 \\
0 \text { if } y_{i}>0
\end{array}\right\}
$$

where $q_{\mathrm{i}}$ was the dichotomous lefthand variable, which indicated the presence of a zero in the harvest variable. A zero value of harvest $\left(q_{\mathrm{i}}=1\right)$ was recorded if a household either did not pursue the specific species of interest or did pursue the particular species but did not report a harvest quantity for the resource in question (e.g., if the hunt was unsuccessful). In the second stage, parameters relating the covariates to reported household harvest quantity were obtained through the use of a truncated negative binomial (NB) count data distribution. The truncated NB distribution is suitable when the dependent variable is represented by the number of event occurrences or by a count (e.g., the count of kilograms harvested by a household for each of the four modeled species). Under the ZINB approach, estimates from the harvest model account for the likelihood that the household reported a harvest quantity.

Vuong test statistics (Vuong, 1989) were used to compare the ZINB specification against the more traditional standard negative binomial model to evaluate goodness of fit. The test result was used to evaluate whether model fit improves by controlling for the presence of zeroes in the dependent variable. Positive values for the Vuong statistic were taken to favor the ZINB specification, while negative values indicated that model fit was improved through standard NB estimation. In each case, controlling for the presence of excess zeroes (by estimating a separate logit equation) improved model fit. Likelihood factors were calculated by taking the exponential function of the estimated parameters for both the logit and count components of the ZINB models.

To provide an indication of the economic importance of subsistence harvest, we used model estimates to calculate a set of hypothetical replacement values for each PZ community. It is important to note that a direct monetary value of subsistence food production was unavailable since no formal exchange markets exist. The calculated replacement values provide a reference point, albeit imperfect, that helps to illustrate the economic contribution of subsistence to $\mathrm{PZ}$ communities. Estimated models were used to generate two sets of mean household harvest predictions for PZ communities for both the total harvested combined weight of caribou and moose and total harvested combined weight of salmon and whitefish (including sheefish). In the first set, the mean prediction for harvested household weight was calculated evaluating model parameters at their data means and the baseline household income category $(<\$ 25 \mathrm{~K})$. The second set of mean harvest predictions was derived by evaluating the PZ indicator variable at a value of zero and remaining model parameters at their data means. In effect, the second set of harvest predictions describes the estimated pattern of harvest for PZ communities as though they were located in the road-accessible NPZ. The replacement values are the difference between two harvest predictions for each community multiplied by a "replacement value" in recognition that food would have to be purchased in the absence of local subsistence production. These products implicitly 
TABLE 3. Estimated proportional changes $( \pm \mathrm{SE})$ in the likelihood that a household would report a subsistence harvest of zero given a one-unit change in covariate.

\begin{tabular}{|c|c|c|c|c|c|c|}
\hline Variables & Land & Fish & Caribou & Moose & Salmon & Whitefish \\
\hline \multirow[t]{2}{*}{ Project zone } & 0.379 & 1.497 & 0.194 & 1.720 & 2.588 & 0.234 \\
\hline & $(0.074)^{* *}$ & $(0.252)^{*}$ & $(0.041)^{* *}$ & $(0.453)$ & $(0.453)^{* *}$ & $(0.046)$ \\
\hline \multirow[t]{2}{*}{ Female head } & 2.664 & 1.496 & 2.46 & 2.370 & 1.367 & 1.757 \\
\hline & $(0.592)^{* *}$ & $(0.249)^{*}$ & $(0.613)^{* *}$ & $(0.684)^{* *}$ & $(0.232)$ & $(0.439)$ \\
\hline \multirow[t]{2}{*}{$\#$ of children $<10$} & 1.197 & 1.205 & 1.075 & 1.412 & 1.173 & 1.123 \\
\hline & $(0.126)$ & $(0.124)$ & $(0.118)$ & $(0.175)^{* *}$ & $(0.118)$ & $(0.137)$ \\
\hline \multirow{2}{*}{ Alaska Native } & 1.048 & 0.881 & 1.518 & 0.936 & 1.078 & 0.501 \\
\hline & $(0.180)$ & $(0.137)$ & $(0.305)^{*}$ & $(0.194)$ & $(0.169)$ & $(0.101)^{* *}$ \\
\hline \multirow[t]{2}{*}{ Income $25 \mathrm{~K}-50 \mathrm{~K}$} & 1.542 & 0.743 & 1.405 & 1.296 & 0.886 & $(0.297)^{*}$ \\
\hline & $(0.125)$ & $(0.310)$ & $(0.301)$ & 0.765 & $(0.131)$ & $(0.209)$ \\
\hline \multirow[t]{2}{*}{ Income $50 \mathrm{~K}-75 \mathrm{~K}$} & 1.092 & 0.552 & 0.914 & 1.280 & 0.571 & 0.819 \\
\hline & $(0.218)$ & $(0.100)^{* *}$ & $(0.203)$ & $(0.315)$ & $(0.103)^{* *}$ & $(0.207)$ \\
\hline \multirow[t]{2}{*}{ Income $75 \mathrm{~K}-100 \mathrm{~K}$} & 1.400 & 0.737 & 1.144 & 1.281 & 0.669 & 1.335 \\
\hline & $(0.348)$ & $(0.165)$ & $(0.317)$ & $(0.373)$ & $(0.150)$ & $(0.441)$ \\
\hline \multirow[t]{2}{*}{ Income $>100 \mathrm{~K}$} & 1.026 & 0.417 & 0.920 & 1.174 & 0.402 & 0.817 \\
\hline & $(0.234)$ & $(0.093) * *$ & $(0.234)$ & $(0.317)$ & $(0.088)^{*}$ & $(0.242)$ \\
\hline \multirow[t]{2}{*}{ Average age } & 1.005 & 1.010 & 1.005 & 1.004 & 1.007 & 1.000 \\
\hline & $(0.005)$ & $(0.005)^{*}$ & $(0.006)$ & $(0.006)$ & $(0.005)$ & $(0.006)$ \\
\hline \multirow[t]{2}{*}{ Household size } & 0.703 & 0.826 & 0.728 & 0.753 & 0.868 & 0.797 \\
\hline & $(0.041)^{* *}$ & $(0.045)^{* *}$ & $(0.044)^{*}$ & $(0.046)^{* *}$ & $(0.046)^{* *}$ & $(0.047)^{* *}$ \\
\hline Ln \#caribou hunters ${ }^{1}$ & - & - & $\begin{array}{c}1.017 \\
(0.040)\end{array}$ & - & - & - \\
\hline Ln \#moose hunters & - & - & - & $\begin{array}{c}1.143 \\
(0.125)\end{array}$ & - & - \\
\hline Ln \#total hunters & $\begin{array}{c}0.968 \\
(0.072)\end{array}$ & - & - & - & - & - \\
\hline Constant & $\begin{array}{l}4.112 \\
(2.188)^{*}\end{array}$ & $\begin{array}{c}0.915 \\
(0.269)\end{array}$ & $\begin{array}{l}6.425 \\
(2.490) *\end{array}$ & $\begin{array}{l}2.459 \\
(1.754)^{*}\end{array}$ & $\begin{array}{c}1.066 \\
(0.125)\end{array}$ & $\begin{array}{l}16.067 \\
(6.285)^{*}\end{array}$ \\
\hline $\begin{array}{l}\text { Households }(\#=1134) \\
\text { reporting harvest }\end{array}$ & 384 & 607 & 277 & 188 & 541 & 152 \\
\hline Vuong statistic & 12.02 & 13.91 & 9.61 & 5.57 & 13.14 & 4.31 \\
\hline
\end{tabular}

$*=$ significance at $p<0.05$ level; $* *=$ significance at $p<0.01$.

${ }^{1} \mathrm{Ln}=$ the natural log function of non-local hunters.

assume only partial replacement of harvested food by purchased food. Fall (2014) provided a range of subsistence harvest replacement values for Alaska regions based on expense equivalences of US\$4 or $\$ 8 /$ U.S. pound ( $\$ 8.82$ or $17.64 / \mathrm{kg}$ ). The upper bound replacement value of $\$ 17.64 / \mathrm{kg}$ was used for both the total land (caribou and moose) harvest and the total fish harvest (salmon, sheefish, and whitefish).

\section{RESULTS}

PZ households were larger, had more children under age 10 , and had a higher proportion of female heads of household than NPZ households (Table 2). The proportion of Alaska Native households was also significantly higher in PZ communities. Average household incomes, both earned and unearned, were not statistically different between the PZ and NPZ communities. Finally, the six-year averages of the number of moose and caribou hunters accessing game management sub-units in the NPZ were significantly higher than those for PZ game management sub-units. Greater road accessibility was correlated to an increased number of non-local hunters who accessed a game management subunit; however, with our data, it was not possible to discern whether those road communities had more hunters prior to the introduction of a road. Higher densities of hunters near roads have been documented elsewhere (e.g., Diefenbach et al., 2005).

Table 3 presents the likelihood factors for the logit estimates, and Table 4 presents incidence rate ratios for the negative binomial estimates. Likelihood factors are positive because the probability (or count) is bounded from below by zero. For logit estimates, likelihood factors are the ratio of the probability that a household did not report harvest to the likelihood that a household did report harvest, for a oneunit change in the explanatory covariate. A factor value of less than one indicated that, for the variable in question, a household was more likely to have reported a harvest. Likewise, factors with a value greater than one indicated that a household was more likely to have reported no harvest. For the negative binomial estimates, incidence rate ratios are directly interpreted as the change in harvested kilograms associated with a one-unit change in the covariate. Statistical significance is reported for $p<0.05$ levels and better across all models.

\section{Model Results - Land}

For model estimates in which the total harvested kilograms of moose and caribou served as the dependent 
TABLE 4. Estimated proportional changes $( \pm \mathrm{SE})$ in household subsistence harvest for a one-unit change in covariate.

\begin{tabular}{|c|c|c|c|c|c|c|}
\hline Variables & Land & Fish & Caribou & Moose & Salmon & Whitefish \\
\hline \multirow[t]{2}{*}{ Project zone } & 2.422 & 1.822 & 4.092 & 1.000 & 1.146 & 9.941 \\
\hline & $(0.270)^{* *}$ & $(0.247)^{* *}$ & $(0.719)^{* *}$ & $(0.074)$ & $(0.169)$ & $(2.226)^{* *}$ \\
\hline \multirow[t]{2}{*}{ Female head } & 0.897 & 0.825 & 0.708 & 1.091 & 0.814 & 0.980 \\
\hline & $(0.118)$ & $(0.122)$ & $(0.112)^{*}$ & $(0.096)$ & $(0.169)$ & $(0.298)$ \\
\hline \multirow[t]{2}{*}{$\#$ of children $<10$} & 0.890 & 0.851 & 0.918 & 0.938 & 0.828 & 1.016 \\
\hline & $(0.044)^{*}$ & $(0.067)^{*}$ & $(0.052)$ & $(0.034)$ & $(0.063)^{*}$ & $(0.165)$ \\
\hline \multirow[t]{2}{*}{ Alaska Native } & 1.354 & 1.549 & 1.529 & 1.031 & 1.636 & 1.144 \\
\hline & & $(0.141)^{* *}$ & $(0.186)^{* *}$ & $(0.059)$ & $(0.194)^{* *}$ & $(0.263)$ \\
\hline \multirow{2}{*}{ Income $25 \mathrm{~K}-50 \mathrm{~K}$} & 0.737 & 0.892 & 0.722 & 0.922 & 0.972 & 1.127 \\
\hline & $(0.078)^{* *}$ & $(0.126)$ & $(0.093)^{*}$ & $(0.064)$ & $(0.136)$ & $(0.314)$ \\
\hline \multirow[t]{2}{*}{ Income $50 \mathrm{~K}-75 \mathrm{~K}$} & 0.878 & 0.968 & 1.029 & 0.867 & 0.950 & 1.113 \\
\hline & $(0.093)$ & $(0.138)$ & $(0.128)$ & $(0.061)^{*}$ & $(0.133)$ & $(0.323)$ \\
\hline \multirow[t]{2}{*}{ Income $75 \mathrm{~K}-100 \mathrm{~K}$} & 0.912 & 1.074 & 0.966 & 0.839 & 1.189 & 0.653 \\
\hline & $(0.117)$ & $(0.193)$ & $(0.147)$ & $(0.070)^{*}$ & $(0.209)$ & $(0.264)$ \\
\hline \multirow[t]{2}{*}{ Income $>100 \mathrm{~K}$} & 0.862 & 1.010 & 0.888 & 0.841 & 1.079 & 1.271 \\
\hline & $(0.103)$ & $(0.179)$ & $(0.128)$ & $(0.065)^{*}$ & $(0.168)$ & $(0.520)$ \\
\hline \multirow[t]{2}{*}{ Average age } & 0.998 & 1.004 & 0.998 & 0.995 & 1.000 & 1.020 \\
\hline & $(0.003)$ & $(0.004)$ & $(0.003)$ & $(0.002)^{* *}$ & $(0.004)$ & $(0.008)$ \\
\hline \multirow[t]{2}{*}{ Household size } & 1.091 & 1.104 & 1.086 & 1.017 & 1.077 & 1.086 \\
\hline & $(0.031)^{* *}$ & $(0.047)^{*}$ & $(0.036)^{*}$ & $(0.018)$ & $(0.045)$ & $(0.087)^{* *}$ \\
\hline Ln \#caribou hunters ${ }^{1}$ & - & - & $\begin{array}{c}0.973 \\
(0.027)\end{array}$ & - & - & - \\
\hline Ln \#moose hunters & - & - & - & $\begin{array}{l}0.918 \\
(0.029)^{* *}\end{array}$ & - & - \\
\hline Ln \#total hunters & $\begin{array}{c}0.958 \\
(0.040)\end{array}$ & - & - & - & - & - \\
\hline \multirow[t]{2}{*}{ Constant } & 272.009 & 107.532 & 106.682 & 573.94 & 145.61 & 6.035 \\
\hline & $(80.22)^{*}$ & $(25.16)^{*}$ & $(24.92) *$ & $(120.55)^{*}$ & $(35.17) *$ & $(2.698) *$ \\
\hline $\begin{array}{l}\text { Households }(\#=1134) \\
\text { reporting harvest }\end{array}$ & 384 & 607 & 277 & 188 & 542 & 152 \\
\hline Vuong statistic & 12.02 & 13.91 & 9.61 & 5.57 & 13.61 & 4.31 \\
\hline
\end{tabular}

$*$ = significance at $p<0.05$ level; $* *=$ significance at $p<0.01$.

${ }^{1} \mathrm{Ln}=$ the natural $\log$ function of non-local hunters.

variable (Land), a total of 384 households reported harvest. Our results indicated that PZ households were more likely to have reported the harvest of moose or caribou and reported greater quantities (in total). Households in the PZ were roughly $38 \%$ as likely as NPZ households to have reported a harvest value of zero (Table 3), while the estimated average reported harvest for PZ households was approximately 2.5 times that of NPZ households (Table 4). The regional difference is explained by differences in the specific species harvested (e.g., caribou vs. moose). Households in the PZ were both more likely to have harvested caribou and estimated to report greater quantities. Households in the PZ were roughly one-fifth as likely to report that they did not harvest caribou (Table 3), and their caribou harvest was 4.1 times that of NPZ households that harvested caribou (Table 4). This pattern did not hold for reported moose harvest; PZ households were estimated to be 1.7 times as likely to report a moose harvest of zero (Table 3), and the estimated moose harvest quantities reported by $\mathrm{PZ}$ and NPZ households were not significantly different (Table 4). Although Alaska Native and non-Native households were estimated to be equally likely to have reported a zero harvest for combined total caribou and moose, Native households were estimated to harvest $1.4 \mathrm{~kg}$ for every $1 \mathrm{~kg}$ harvested by non-Native households (Table 4). The difference in harvest quantities is attributable to the significant difference in caribou harvests: Alaska Native households were estimated to harvest approximately 1.5 times the quantity of caribou harvested by non-Native households (Table 4). Household moose harvest was not estimated to be different between Alaska Native and non-Native households.

Household income is estimated to have little relative effect on either the likelihood that a household pursued caribou or moose or the total quantities of moose and caribou harvested overall. When compared to households reporting income of less than $\$ 25 \mathrm{~K}$, households earning $\$ 25 \mathrm{~K}-\$ 50 \mathrm{~K}$ were estimated to be approximately 1.5 times as likely to have reported a harvest of zero for the combined harvest of caribou and moose (Table 3). Likewise, the estimated combined moose and caribou harvest for households earning $\$ 25 \mathrm{~K}-\$ 50 \mathrm{~K}$ was approximately $74 \%$ of that of households earning less than $\$ 25 \mathrm{~K}$ (Table 4). While the caribou harvest followed a similar pattern, the moose harvest was estimated to be sensitive to increases in household income. Households earning more than $\$ 50 \mathrm{~K}$ were estimated to harvest $84 \%$ to $87 \%$ of the moose harvest of households earning less than $\$ 25 \mathrm{~K}$ (Table 4).

Increased pressure from outside (non-local) hunters was not estimated to have a significant impact on either the probability that a household reported harvesting moose or caribou or the overall quantity of moose and caribou 
(combined) harvested. However, the estimated quantity of moose harvested (Table 4) was inversely related to the number of non-local moose hunters. For each $1 \%$ increase in the number of moose hunters in a game management sub-unit, households were estimated to harvest approximately $8 \%$ less moose.

For the remaining covariates, both the likelihood that a household reported a harvest and the total reported harvested weight of moose and caribou were estimated to increase with household size. The addition of one individual to household size reduced the likelihood that a household did not harvest moose or caribou, and overall harvest of caribou and moose increased by approximately $9 \%$ for each additional individual in the household. This effect was also seen in the caribou-only model, where the addition of one individual to household size was estimated to increase the harvest of caribou by approximately $8.6 \%$.

Model Results - Fish

A total of 607 respondent households indicated participation in the harvest of salmon, whitefish, or sheefish (All Fish). The estimated overall model for fish indicated that PZ households were approximately 1.5 times as likely to have reported a harvest value of zero (Table 3). While PZ households are less likely to have reported the harvest of fish, those that did report harvest were estimated to harvest 1.8 times the quantity of NPZ households. Again, the differences in regional harvest patterns are driven by differences in the fish species pursued. Specifically, households in PZ communities harvested close to 10 times the quantity of whitefish (including sheefish) harvested by NPZ households (Table 4). While PZ households are approximately 2.6 times as likely to have reported a harvest of zero for salmon (Table 3), no statistically significant difference in the estimated quantities of salmon harvested by PZ and NPZ households was evident (Table 4). Alaska Native households were equally likely to report a zero value for fish overall, and salmon and whitefish in particular, as non-Native households (Table 3). Estimated harvests by Alaska Native households, however, were 1.5 times as large as those of non-Native households (Table 4). The overall difference in fish harvest between Alaska Native and nonNative households was driven by the significantly larger harvest of salmon. Alaska Native households were estimated to harvest 1.6 times the quantity of salmon harvested by non-Native households (Table 4). Households headed by females, however, were estimated to be 1.5 times as likely to report a zero harvest of fish, overall, and 1.8 times as likely to report a zero harvest for whitefish (Table 3). No statistically significant differences in harvest quantity between female-headed households and those headed by males were estimated.

Households with incomes between $\$ 50 \mathrm{~K}$ and $\$ 75 \mathrm{~K}$, when compared to households earning less than $\$ 25 \mathrm{~K}$, were estimated to be about half (55\%) as likely to report a zero harvest for all fish (Table 3). Relative household income is not estimated to be significant in the whitefish model. The estimated effects of household income on fish harvest overall can be seen in the estimated relationship between salmon harvest and relative household income. Compared to households earning less than $\$ 25 \mathrm{~K}$, households earning $\$ 50 \mathrm{~K}-\$ 75 \mathrm{~K}$ were only $57 \%$ as likely (and those with incomes $>\$ 100 \mathrm{~K}$ were only $40 \%$ as likely) to have reported a zero harvest for salmon. Household income was not estimated to affect the quantity of salmon harvested.

For the remaining covariates, household size was estimated to reduce the likelihood of observing an overall fish harvest level of zero (Table 3). Similar outcomes were estimated for the likelihood of reporting a zero harvest of salmon or of whitefish (Table 3). Overall household fish harvest quantities were estimated to increase by $10 \%$ for each additional individual living in the household. The change in overall fish harvest associated with household size is also seen in the salmon and whitefish models: each additional person in the household was estimated to increase the reported salmon harvest by $7.7 \%$ and that of whitefish by $8.6 \%$.

\section{Predicted Household Harvest and Replacement Values}

Harvest predictions are shown for combined moose and caribou harvest in Table 5 and combined harvest of salmon and whitefish in Table 6. Each table shows two mean harvest predictions (edible weight in $\mathrm{kg}$ ), the difference between them, and the dollar value of that difference. As noted earlier, the simple replacement values presented are based on the upper bound per unit cost equivalence provided by Fall (2014). This value provides a monetary cost equivalence benchmark for subsistence production given the absence of market-based values. We note that more representative cost equivalences could be developed for each community on the basis of local food costs and nutritional equivalences between subsistence and store-bought food. Nevertheless, the provided replacement values at least give a partial monetary reference point for the value of subsistence production.

Replacement values for the predicted difference ranged from $\$ 2239$ to $\$ 7176$ for the combined caribou and moose harvest and from $\$ 1341$ to $\$ 3392$ for the combined harvest of salmon and whitefish (including sheefish). In aggregate, the predicted replacement values ranged from approximately $\$ 6900$ to $\$ 10500$ for PZ communities located off the existing road system (including the Bettles ice road).

\section{DISCUSSION}

Roads have far-ranging, complex, and penetrating effects on human lifestyles, wildlife, their habitat, and interactions of people with wildlife, including subsistence activities. We found that total household subsistence harvest levels, driven largely by the greater caribou and whitefish harvests, were 2.5 times greater in $\mathrm{PZ}$ communities than in road accessible 
TABLE 5. Mean predicted caribou and moose harvests $( \pm$ SD) for communities in Project Zone. Column 3 shows corresponding mean $( \pm$ SD) values evaluating these communities as though they were NPZ communities, and column 4 the difference between the two means. Column 5 shows the US\$ value $( \pm \mathrm{SD}$ ) of that difference using Fall's (2014) replacement value of \$17.64/kg.

\begin{tabular}{|c|c|c|c|c|}
\hline Community & $\begin{array}{l}\text { Mean predicted harvest } \\
\text { (edible weight in } \mathrm{kg} \text { ) }\end{array}$ & $\begin{array}{c}\text { Mean predicted harvest } \\
\text { evaluated as NPZ }\end{array}$ & Difference in means & $\begin{array}{l}\text { US\$ value of } \\
\text { difference }\end{array}$ \\
\hline Alatna & $646.084(115.152)$ & $266.702(47.535)$ & $379.383(67.618)$ & 6692.32 (1192.78) \\
\hline Allakaket & $649.787(123.496)$ & $268.230(50.979)$ & $381.557(72.518)$ & $6730.67(1279.21)$ \\
\hline Ambler & $612.257(158.955)$ & $252.738(65.616)$ & 359.519 (93.339) & $6341.92(1646.51)$ \\
\hline Anaktuvuk Pass & $692.867(154.944)$ & $286.013(63.961)$ & $406.854(90.984)$ & $7176.90(1604.96)$ \\
\hline Bettles & $460.518(75.382)$ & 190.101 (31.117) & $270.418(44.265)$ & $4770.18(780.83)$ \\
\hline Coldfoot & $216.236(6.536)$ & $89.262(2.698)$ & $126.975(3.838)$ & 2239.83 (67.699) \\
\hline Evansville & $504.422(103.104)$ & $208.224(42.561)$ & $296.199(60.543)$ & $5224.94(1067.99)$ \\
\hline Kobuk & $617.930(219.099)$ & $255.080(90.443)$ & $362.851(128.656)$ & $6400.69(2269.49)$ \\
\hline Shungnak & 603.047 (149.758) & $248.936(61.820)$ & $354.112(87.938)$ & $6246.53(1551.23)$ \\
\hline Wiseman & 504.751 (92.934) & $208.360(38.363)$ & $296.392(54.571)$ & 5228.35 (962.64) \\
\hline
\end{tabular}

TABLE 6. Predicted harvest means ( \pm SD) for combined salmon and whitefish harvest and value difference in US\$ ( \pm SD) using Fall's (2014) replacement value of $\$ 17.64 / \mathrm{kg}$.

\begin{tabular}{|c|c|c|c|c|}
\hline Community & $\begin{array}{l}\text { Mean predicted harvest } \\
\text { (edible weight in } \mathrm{kg} \text { ) }\end{array}$ & $\begin{array}{c}\text { Mean predicted harvest } \\
\text { evaluated as NPZ }\end{array}$ & Difference in means & $\begin{array}{l}\text { US\$ value of } \\
\text { difference }\end{array}$ \\
\hline Alatna & $352.095(67.685)$ & $193.291(37.157)$ & $158.804(30.528)$ & $2801.29(538.51)$ \\
\hline Allakaket & $415.153(99.006)$ & $227.909(54.352)$ & $187.219(44.654)$ & $3302.98(787.70)$ \\
\hline Ambler & $414.061(125.538)$ & $227.310(68.918)$ & $186.751(56.620)$ & 3294.29 (998.79) \\
\hline Anaktuvuk Pass & $418.537(109.034)$ & 229.767 (59.857) & $188.770(49.177)$ & $3329.90(867.48)$ \\
\hline Bettles & $268.909(57.045)$ & $147.625(31.316)$ & $121.284(25.729)$ & $2139.46(453.85)$ \\
\hline Coldfoot & $168.626(5.918)$ & $92.572(3.249)$ & $76.054(2.669)$ & $1341.60(48.09)$ \\
\hline Evansville & $308.436(75.597)$ & $169.324(41.501)$ & $139.112(34.096)$ & $2453.93(601.45)$ \\
\hline Kobuk & $413.928(175.325)$ & $227.236(96.249)$ & $186.692(79.076)$ & $3293.23(1394.90)$ \\
\hline Shungnak & $426.426(147.861)$ & $234.098(81.172)$ & $192.328(66.689)$ & $3392.67(1176.39)$ \\
\hline Wiseman & $298.53(51.949)$ & $163.844(28.519)$ & $134.609(23.430)$ & $2374.51(413.31)$ \\
\hline
\end{tabular}

NPZ communities. Biological productivity sharply declines at higher latitudes (Field et al., 1998). Thus, both ungulate and fish resources should be more plentiful for NPZ communities than for PZ communities. That we found the opposite relationship highlights the importance of human influence (increased access, harvest, and competition) on subsistence resources. While lower harvest limits and shorter hunting seasons are found near NPZ communities, they are not the root cause of lower subsistence production. The shorter hunting seasons and lower harvest limits and subsistence harvests may be the product of diminished populations of subsistence species. Increased access and numbers of hunters, as well as natural fluctuations, can reduce these populations. Thus, if access increased and greater pressure arose in areas around $\mathrm{PZ}$ communities, one should expect that those regions would get more restrictions on harvests.

Our analyses show that PZ communities are heavily reliant on the subsistence harvest, a finding that concurs with other studies (Wolfe and Walker, 1987; Huskey, 2004; Goldsmith, 2007; Fall, 2014, 2016; Braem et al., 2015). Likewise, Alaska Native households were estimated to have higher levels of subsistence production. While a large share of households reported being engaged in the harvest of fish and large animals, most of the harvest is collected by a relatively small proportion of households. Wolfe et al. (2009) reported that approximately $33 \%$ of the households produced $76 \%$ of the subsistence harvests, and these figures are very similar to our results. This finding suggests that community welfare can depend upon the success or failure of a small number of households.

Our findings suggest that the decision to engage in subsistence activities differs between PZ and NPZ communities and that household characteristics affect both the decision and the amount harvested. We found that households with more children age 10 and younger had greater subsistence productivity, but households headed by females reported lower harvest of big game species such as moose and caribou.

One of the primary perceived benefits of building a road to the Ambler Mining District is the potential for increased economic opportunities. Indeed, one economic impact analysis suggests that up to 13 jobs for the entire PZ may be directly created for the operation and maintenance of the road (Cardno, 2015). However, when changes to the (noncash) subsistence economy are taken into account, a more complex picture of both positive and negative economic effects emerges. For example, households with higher incomes do not necessarily have higher subsistence harvest than lower-income households. To the contrary, we found that PZ and NPZ households with higher incomes were estimated to have lower caribou and moose harvests than households earning less than $\$ 25 \mathrm{~K}$. Similarly, an inverse relationship between community income and harvest level has also been reported in other studies, notably Wolfe and Walker (1987), and Wolfe (2004). At this time, what is 
driving the relationship between subsistence harvest and household income remains an open question.

An analytical problem associated with the data we used was that the household unit exists within a larger community subsistence network. As noted by Braem et al. (2015:63), "While subsistence harvest surveys collect information based on individual households, in reality, much of the production (harvest and processing) of subsistence foods is achieved by households within a community that work cooperatively." Magdanz et al. (2002) noted that harvests occur within extended family networks that transcend a single household. Although household surveys have expanded to include information on network sharing relationships, they do not document quantities harvested, distributed, and used across households. Consequently, it was not possible to incorporate unobserved social connections within our models.

The productivity of the habitat and relative lack of competition help to explain a portion of the significant differences in harvest levels between the PZ and NPZ households. Households in Ambler, Kobuk, and Shungnak benefited from access to productive whitefish fisheries that remain relatively unaffected by outside competition because of the lack of roads in the region. Similarly, these communities have better access to the Western Arctic Herd, which for several decades was the largest caribou herd in the state (Wilson et al., 2014). Fewer hunters may also correlate with higher hunter success rates. Moose and salmon abundance is greater in the NPZ region.

In our analysis, we assumed that the road would eventually be open to public access. Road access could increase competition for finite subsistence resources from hunters residing outside the study area (i.e., hunters that are not eligible to partake in subsistence as outlined by ANILCA). While our non-local hunter proxy was not estimated to have a significant impact on the combined harvest quantity of moose and caribou or of caribou individually, the quantity of moose harvested was inversely related to the sixyear average number of non-local moose hunters accessing game management sub-units in which the communities are located. In other words, our results suggest that if the road should increase the number of non-local moose hunters, the quantity of moose harvested by PZ households should be expected to decline. Specifically, for every $1 \%$ increase in the number of moose hunters, we estimated that PZ households would harvest $8 \%$ less moose than if those hunters were not provided access to the region. While our results are not causal, they suggest that already vulnerable areas may be further jeopardized by additional outside stresses and that the effects of the additional competition will be unevenly distributed in relation to household composition. NPZ communities are closer to the population centers of Alaska than PZ communities, which could dampen the impact of competition on $\mathrm{PZ}$ communities compared to NPZ communities.

Finally, drawing on Fall's (2014) results and assuming that the pattern of subsistence production for off-road PZ communities would be similar to that of NPZ communities after the addition of a road to the Ambler Mining District, we calculated that an average household that is currently off the existing road system may see a loss of subsistence production valued at $\$ 6900$ to $\$ 10500$ per household per year. This loss is roughly equivalent to $33 \%$ of the median income for these households (U.S. Census Bureau, 2010). The percentage is greater in the Interior villages: the loss represents $62 \%$ of the median income in households in Allakaket (U.S. Census Bureau, 2010). Though the proposed road would not directly reach any PZ community, it has been estimated that if fuel could be shipped from the road to communities (perhaps via an ice road), there could be a savings on heat and electricity of $\$ 2755$ to $\$ 3737$ per household per year (Cardno, 2015), which is roughly onethird to one-half of the lower-end value of subsistence production we estimated. Potentially, store-bought food could also be shipped to replace reductions in subsistence harvests for communities near the proposed road. For communities farther from the proposed road, such as Allakaket, complete replacement should not be expected. Indeed, scenarios for even partial replacement are difficult to ascertain. A comprehensive review of the interplay between the possible reduction in commodity prices and the added hunting pressure is beyond the scope of our analysis, but highlighting the contributing factors affecting the harvest decision and harvest amount of households in the region should assist policy makers in thinking about the implications of the Ambler Road project. Our results suggest that a road through this region could have substantial impacts on subsistence production of affected communities.

\section{ACKNOWLEDGEMENTS}

Valuable comments were provided by J. Rasic, B. Cellarius, and anonymous reviewers on an earlier draft of this manuscript. A. Baltensperger created the study area map. Funding for this project was provided by the National Park Service.

\section{REFERENCES}

ADF\&G (Alaska Department of Fish and Game). 2015. Community household surveys of harvests and uses of subsistence resources. Unpubl. database. Anchorage: ADF\&G, Subsistence Division.

Anderson, D.B., Anderson, W.W., Bane, R., Nelson, R.K, and Towarak, N.S. 1977. Kuuvanmiut subsistence: Traditional Eskimo life in the latter twentieth century. Washington, D.C.: U.S. Department of the Interior, National Park Service.

Berger, J. 2004. The last mile: How to sustain long-distance migration in mammals. Conservation Biology 18(2):320-331. http://dx.doi.org/10.1111/j.1523-1739.2004.00548.x 
Berger, J., and Daneke, D. 1988. Effects of agricultural, industrial, and recreational expansion on frequency of wildlife law violations in the central Rocky Mountains, USA. Conservation Biology 2(3):283-289. http://dx.doi.org/10.1111/j.1523-1739.1988.tb00185.x

Braem, N.M., Mikow, E.H., Wilson, S.J., and Kostick, M.L. 2015. Wild food harvests in 3 upper Kobuk River communities: Ambler, Shungnak, and Kobuk, 2012-2013. Technical Paper No. 402. Fairbanks: Alaska Department of Fish and Game, Division of Subsistence.

Brehmer, E. 2014. Lawmakers briefed on Ambler, Juneau road projects. Alaska Journal of Commerce (March-Issue-3). Anchorage, Alaska.

ht t p : // w w w a laskajournal.com/busines s - and finance/2014-03-13/lawmakers-briefed-ambler-juneau-roadprojects\#.VrI58rIrJhF

Brown, T.C., and Burch, E.S., Jr. 1992. Estimating the economic value of subsistence harvest of wildlife in Alaska. In: Peterson, G.L., Swanson C.S., McCollum, D.W., and Thomas, M.H., eds. Valuing wildlife resources in Alaska. Boulder, Colorado: Westview Press. 203-254.

Buxton, M. 2014a. Allakaket speaks out against Ambler road, potential harm to subsistence lifestyle. Fairbanks Daily News Miner, July 26.

http://www.newsminer.com/news/local_news/allakaketspeaks-out-against-ambler-road-potential-harm-tosubsistence/article_4fc40bc0-1499-11e4-9704-0017a43b2370. html

2014b. Interior Alaska residents voice concerns at meeting on proposed Ambler Road. Fairbanks Daily News Miner, December 17.

http://www.newsminer.com/news/local_news/interior-alaskaresidents-voice-concerns-at-meeting-on-proposed-ambler/ article_15fff5ac-8690-11e4-a7a5-3b40a6341077.html

Cameron, A.C., and Trivedi, P.K. 1998. Regression analysis of count data. New York: Cambridge University Press. http://dx.doi.org/10.1017/CBO9780511814365

Cardno. 2015. Ambler mining region economic impact analysis. Cardno Project Number - ES14004900. Portland, Oregon: Cardno.

http://www.ambleraccess.org/projects/ambler/documents/ final_ambler_mining_economic_impact_analysis_feb_2015. pdf

Cole, E.K., Pope, M.D., and Anthony, R.G. 1997. Effects of road management on movement and survival of Roosevelt elk. Journal of Wildlife Management 61(4):1115-1126.

http://dx.doi.org/10.2307/3802109

Diefenbach, D.R., Finley, J.C., Luloff, A.E., Stedman, R., Swope, C.B., Zinn, H.C., and San Julian, G.J. 2005. Bear and deer hunter density and distribution on public land in Pennsylvania. Human Dimensions of Wildlife 10(3):201-212. http://dx.doi.org/10.1080/10871200591003445

Fall, J.A. 1990. The Division of Subsistence of the Alaska Department of Fish and Game: An overview of its research program and findings: 1980-1990. Arctic Anthropology 27(2):68-92.
2014. Subsistence in Alaska: A year 2012 update. Anchorage: Alaska Department of Fish and Game, Division of Subsistence.

https://www.adfg.alaska.gov/static/home/subsistence/pdfs/ subsistence_update_2012.pdf

- 2016. Regional patterns of fish and wildlife harvests in contemporary Alaska. Arctic 69(1):47-64.

http://dx.doi.org/10.14430/arctic4547

Field, C.B., Behrenfeld, M.J., Randerson, J.T., and Falkowski, P. 1998. Primary production of the biosphere: Integrating terrestrial and oceanic components. Science 281(5374):237-240. http://dx.doi.org/10.1126/science.281.5374.237

Forman, R.T.T., and Alexander, L.E. 1998. Roads and their major ecological effects. Annual Review of Ecology and Systematics 29:207-231.

http://dx.doi.org/10.1146/annurev.ecolsys.29.1.207

Forman, R.T.T., Sperling, D., Bissonette, J.A., Clevenger, A.P., Cutshall, C.D., Dale, V.H., Fahrig, L., et al. 2003. Road ecology: Science and solutions, $2^{\text {nd }}$ ed. Washington, D.C.: Island Press.

Fuller, A. 2007. Boomtown blues: How natural gas changed the way of life in Sublette County. The New Yorker, February 5.

Goldsmith, S. 2007. The remote rural economy of Alaska. Anchorage: Institute of Social and Economic Research, University of Alaska Anchorage.

Gude, P.H., Hansen, A.J., and Jones, D.A. 2007. Biodiversity consequences of alternative future land use scenarios in Greater Yellowstone. Ecological Applications 17(4):1004-1018. http://dx.doi.org/10.1890/05-1108

Haines, A.M., Elledge, D., Wilsing, L.K., Grabe, M., Barske, M.D., Burke, N., and Webb, S.L. 2012. Spatially explicit analysis of poaching activity as a conservation management tool. Wildlife Society Bulletin 36(4):685-692. http://dx.doi.org/10.1002/wsb.194

Holen, D., Hazell, S.M., and Koster, D.S., eds. 2012. Subsistence harvests and uses of wild resources by communities in the eastern interior of Alaska, 2011. Technical Paper No. 372. Fairbanks: Alaska Department of Fish and Game, Division of Subsistence.

Holen, D., Hazell, S.M., and Zimpelman, G., eds. 2015. The harvest and use of wild resources in selected communities of the Copper River Basin and East Glenn Highway, Alaska, 2013. Technical Paper No. 405. Fairbanks: Alaska Department of Fish and Game, Division of Subsistence.

Huskey, L. 2004. Alaska's village economies. Journal of Land, Resources, \& Environmental Law 24(3):435-464.

Joly, K. 2012. Sea ice crossing by migrating caribou, Rangifer tarandus, in north-western Alaska. Canadian Field-Naturalist 126(3):217-220.

Kruse, J. 1991. Alaska Inupiat subsistence and wage employment patterns: Understanding individual choice. Human Organization 50(4):317-326. http://dx.doi.org/10.17730/humo.50.4.c288gt2641286g71

Kukkonen, M., and Zimpelman, G. 2012. Subsistence harvests and uses of wild resources in Chistochina, Alaska, 2009. Technical Paper No. 370. Anchorage: Alaska Department of Fish and Game, Division of Subsistence. 
Lambert, D. 1992. Zero-inflated Poisson regression, with an application to defects in manufacturing. Technometrics 34(1): $1-14$. http://dx.doi.org/10.2307/1269547

La Vine, R., and Zimpelman, G., eds. 2014. Subsistence harvests and uses of wild resources in Kenny Lake/Willow Creek, Gakona, McCarthy, and Chitina, Alaska, 2012. Technical Paper No. 394. Anchorage: Alaska Department of Fish and Game, Division of Subsistence.

La Vine, R., Kukkonen, M., Jones, B., and Zimpelman, G. 2013. Subsistence harvests and uses of wild resources in Copper Center, Slana/Nabesna Road, Mentasta Lake, and Mentasta Pass, Alaska, 2010. Technical Paper No. 380. Anchorage: Alaska Department of Fish and Game, Division of Subsistence.

Magdanz, J.S., Utermohle, C.J., and Wolfe, R.J. 2002. The production and distribution of wild food in Wales and Deering, Alaska. Technical Paper No. 259. Juneau: Alaska Department of Fish and Game, Division of Subsistence.

McDowell Group. 2009. Alaska geographic differential study 2008. Prepared for the State of Alaska, Department of Administration.

http://doa.alaska.gov/dop/gds/home.html

McLellan, B.N., and Shackleton, D.M. 1988. Grizzly bears and resource-extraction industries: Effects of roads on behaviour, habitat use and demography. Journal of Applied Ecology 25(2):451-460.

http://dx.doi.org/10.2307/2403836

Mittermeier, R.A., Mittermeier, C.G., Brooks, T.M., Pilgrim, J.D., Konstant, W.R., da Fonseca, G.A.B., and Kormos, C. 2003. Wilderness and biodiversity conservation. Proceedings of the National Academy of Sciences 100(18):10309-10313. http://dx.doi.org/10.1073/pnas.1732458100

NCEI (National Centers for Environmental Information). 2015. Annual summaries station details: Bettles Airport, AK US. http://www.ncdc.noaa.gov/cdo-web/datasets/ANNUAL/ stations/COOP:500761/detail

Norris, F. 2002. Alaska subsistence: A National Park Service management history. Anchorage: U.S. Department of the Interior, National Park Service.

Power, T.M. 1996. Lost landscapes and failed economies: The search for a value of place. Covello, California: Island Press.

U.S. Census Bureau. 2010. 2010 census data. http://www.census.gov/2010census/data/
Vuong, Q.H. 1989. Likelihood ratio tests for model selection and non-nested hypotheses. Econometrica 57(2):307-333. http://dx.doi.org/10.2307/1912557

Walker, D.A., and Everett, K.R. 1987. Road dust and its environmental impact on Alaskan taiga and tundra. Arctic and Alpine Research 19(4):479-489. http://dx.doi.org/10.2307/1551414

Watson, A. 2014. Preliminary traditional and local ecological knowledge (TEK/LEK) study of the impacts by the proposed road to Ambler on the communities of Allakaket and Alatna. Charleston, South Carolina: College of Charleston.

Wheeler, P., and Thornton, T. 2005. Subsistence research in Alaska: A thirty year retrospective. Alaska Journal of Anthropology 3(1):69-103.

Whiting, A. 2004. The relationship between Qikiktagrugmiut (Kotzebue Tribal Members) and the Western Arctic parklands, Alaska, United States. International Journal of Wilderness 10(2):28-32.

Wilson, R.R., Gustine, D.D., and Joly, K. 2014. Evaluating potential effects of an industrial road on winter habitat of caribou in north-central Alaska. Arctic 67(4):472-482. http://dx.doi.org/10.14430/arctic4421

Wolfe, R.J. 1987. The super-household: Specialization in subsistence economies. Paper presented at the 14th Annual Meeting of the Alaska Anthropological Association, Anchorage, Alaska.

2004. Local traditions and subsistence: A synopsis from twenty-five years of research by the State of Alaska. Technical Paper No. 284. Juneau: Alaska Department of Fish and Game, Division of Subsistence.

Wolfe, R.J., and Walker, R.J. 1987. Subsistence economies in Alaska: Productivity, geography, and development impacts. Arctic Anthropology 24(2):56-81.

Wolfe, R.J., Scott, C.L., Simeone, W.E., Utermohle, C.J., and Pete, M.C. 2009. The 'super-household' in Alaska Native subsistence economies. Final Report to the National Science Foundation, Project ARC 0352611.

Yarnell, R. 2013. State of Alaska should not be surprised that road to Ambler met strong local opposition, Commentary. Alaska Dispatch News, October 13.

http://www.adn.com/commentary/article/state-alaskashould-not-be-surprised-road-ambler-met-strong-localopposition/2013/10/14/ 